\title{
Nitrogen-limited primary productivity of coral reef algal turfs: potential contribution of ammonium excreted by Diadema antillarum*
}

\author{
S. L. Williams ${ }^{1}$, R. C. Carpenter ${ }^{2, * *}$ \\ ${ }^{1}$ Friday Habor Laboratories, University of Washington, 620 University Rd, Friday Harbor, Washington 98250, USA \\ ${ }^{2}$ National Undersea Research Program, West Indies Laboratory, Teague Bay, Christiansted, St Croix, US Virgin Islands 00820
}

\begin{abstract}
Algal turfs account for the majority of the considerable primary productivity exhibited by coral reefs. Algal turfs grazed by the sea urchin Diadema antillarum Philippi are 2 to 10 times more productive per unit chlorophyll a than turfs not grazed by $D$. antillarum. We investigated one of several hypotheses to account for this effect: primary productivity of algal turfs is nutrient-limited and excretion by $D$. antillarum provides a nitrogen supplement to algal turfs. Algal turfs on natural settling plates were fertilized with ammonium, phosphorus, or both, for $17 \mathrm{~d}$ on a backreef in St Croix, US Virgin Islands. Primary productivity per unit chlorophyll a was significantly greater in the ammonium treatment than in the control treatment, although algal biomass in each treatment was not significantly different from the control. Biomass-specific ammonium excretion by $D$. antillarum was correlated with sea urchin size and respiration rates and averaged $115 \mu \mathrm{g} \mathrm{N}$ ind ${ }^{-1} \mathrm{~h}^{-1}$ Excretion was significantly greater during the day than at night. In the field, ammonium concentrations were significantly higher under $D$. antillarum than ambient concentrations, indicating that dissipation of sea urchin excretions was not immediate or complete. Calculations of the nitrogen required for the observed primary productivity of algal turfs indicate that, prior to the mass mortality, up to $19 \%$ could have been supplied by $D$. antillarum excretions
\end{abstract}

\section{INTRODUCTION}

Coral reefs exhibit rates of primary productivity that are among the highest reported for any ecosystem (Lewis 1977). Algal turfs are responsible for the majority of whole reef primary productivity (Johannes et al. 1971, Marsh 1976, Wanders 1976, Hatcher 1981, Carpenter 1985a) due to the high coverage of substratum by this component and very high biomass-specific productivity rates [e. g. 6.4 to $8.0 \mu \mathrm{g} \mathrm{O}_{2}(\mu \mathrm{g} \mathrm{chl} \mathrm{a})^{-1} \mathrm{~h}^{-1}$; Carpenter 1985a]. Algal turfs are densely packed assemblages of unicellular and filamentous algae from at least 5 algal divisions and are characterized by diminutive canopy heights (generally $<5 \mathrm{~mm}$; Wanders 1977, Steneck \& Watling 1982).

Numerous studies have demonstrated the widespread importance of grazing by the sea urchin Diadema antillarum Philippi on benthic algal commun-

\footnotetext{
- Contribution No. 179 from West Indies Laboratory

- Present address: Dept of Biology, California State University, Northridge, California 91330, USA
}

ity biomass, structure and function (Ogden et al. 1973 Sammarco et al. 1974, Carpenter 1981, 1986, Sammarco 1982, Lessios et al. 1984, de Ruyter van Steveninck \& Bak 1986). In this paper, we consider a functional effect of $D$. antillarum grazing: algal turfs grazed by $D$. antillarum are 2 to 10 times more productive per unit chlorophyll a than turfs not grazed by $D$. antillarum (Carpenter 1981, 1985b, 1986). The positive effect of $D$. antillarum grazing on algal turf productivity was corroborated by a $60 \%$ decrease in biomassspecific productivity following the mass-mortality of $D$. antillarum throughout the Caribbean in 1983 and 1984 (Carpenter 1985b, 1988). Population densities of $D$. antillarum were reduced by 90 to $100 \%$ (Lessios et al. 1984) with concomitant increases in algal biomass and changes in community structure (Bak et al. 1984, Ballantine 1984, Lessios et al. 1984, Carpenter 1985b, Liddell \& Ohlhorst 1986).

Several hypotheses may explain the positive effect of grazing by Diadema antillarum on the biomass-specific productivity of algal turfs. One hypothesis is that grazing by $D$. antillarum reduces algal canopy heights 
(grazed height 1 to $2 \mathrm{~mm}$, ungrazed height 4 to $8 \mathrm{~mm}$; Carpenter 1985b), which may minimize algal selfshading and/or facilitate diffusion of carbon and nutrients to the plants. Other hypotheses concern possible nutrient limitation of algal turfs and the role of $D$. antillarum in enhancing nutrient input to algal turfs.

It is currently under debate whether the primary productivity of coral reefs is nutrient-limited and, if so, what nutrient is limiting (Entsch et al. 1973, Smith 1984, Gladfelter \& Kinsey 1985). Increased rates of whole reef primary productivity have resulted from experimental enrichment of a reef with nitrogen and phosphorus, suggesting that reef algae are nutrientlimited (Kinsey \& Domm 1974). Following nitrogen enrichment of another reef, algal turf community structure changed, suggesting nitrogen limitation of at least the algal turf component (Hatcher \& Larkum 1983).

Diadema antillarum may enhance nutrient supply to algal turfs in several ways. For example, grazing may favor growth of cyanobacteria (blue-green algae) in the algal turf community and result in increased rates of $\mathrm{N}_{2}$ fixation per unit area, similar to the effects of fish grazing (Wilkinson \& Sammarco 1983, Wilkinson et al. 1984). Also, soluble excretions from $D$. antillarum may provide a nutrient supplement to algal turfs. Ammonium comprises $>60 \%$ of the nitrogenous excretions of $D$. antillarum (Lewis 1967) which exit from the respiratory surfaces (tube feet, gills). If water exchange with the surroundings is reduced under sea urchins, nitrogenous excretions may remain available for uptake by algae. Nitrogen-fixing bacteria have been isolated from the gut of $D$. antillarum (Guerinot \& Patriquin 1981); thus, excretions may represent a source of both recycled and new nitrogen (sensu Dugdale 1976).

We present results from an experiment designed to test the hypothesis that the primary productivity of coral reef algal turfs is nutrient-limited, and, if it is, whether nitrogen or phosphorus is limiting. In addition, we assess the contribution that ammonium excretions from Diadema antillarum may make to algal turf primary productivity.

\section{METHODS}

Fertilization effects on algal turf primary productivity. Algal turfs were grown on settling plates $(8 \times 8 \times$ $1 \mathrm{~cm}$ ) cut from dead branches of the reef coral Acropora palmata (Carpenter 1985a). Plates were placed at a depth of 1.5 to $2 \mathrm{~m}$ on the backreef of Tague Bay, St Croix, US Virgin Islands, for 10 mo prior to the fertilization experiments. This period is more than sufficient for turfs on the settling plates to resemble those on the surrounding natural substrata (Carpenter 1986). Eighteen plates then were placed in cages with Diadema antillarum at natural densities of 6 sea urchins $\mathrm{m}^{-2}$ (Ogden 1977, Carpenter 1986, Foster 1987) to achieve fairly uniform algal turf biomass among the plates. After $15 \mathrm{~d}, 12$ plates were selected randomly to estimate the light-saturated rate of $\mathrm{O}_{2}$ production in acrylic (Plexiglas) chambers. Duplicate incubations (15 min) were conducted and averaged for each of the 12 plates. The methodology for primary productivity estimates, algal biomass, and chlorophyll à (chl a) followed Carpenter (1985a).

Six additional plates were assigned randomly to each of 4 treatments: (1) unfertilized control; (2) fertilized with ammonium $(+N)$; (3) fertilized with phosphorus $(+P)_{;}$(4) fertilized with ammonium and phosphorus $(+N+P)$. Plates were affixed to aluminum strips which rested on cement blocks ca $30 \mathrm{~cm}$ above the sediments. Nutrient-enrichment treatments were located downstream of the control treatment and were assigned randomly to positions $2 \mathrm{~m}$ apart on a transect perpendicular to the normal net unidirectional water flow to minimize cross-fertilization of the treatments.

Nutrients were released slowly from $250 \mathrm{ml}$ polycarbonate bottles drilled with several small holes and filled with $165 \mathrm{~g} \mathrm{NH} \mathrm{NH}_{4} \mathrm{Cl}$ or $60 \mathrm{~g} \mathrm{KH}_{2} \mathrm{PO}_{4}$, or both, contained in nylon mesh bags. Two bottles were placed in each treatment at the level of the algal canopy and the fertilizer was replaced every $6 \mathrm{~d}$. Concentrations of ammonium (Koroleff 1976) and phosphorus (Parsons et al. 1984) were determined in duplicate daily for $6 \mathrm{~d}$ for each treatment and averaged over the time between successive replacements of nutrient enrichments. After $17 \mathrm{~d}$, rates of primary productivity of algal turfs were estimated. Pairs of plates (1 per chamber) from each treatment were incubated twice for $15 \mathrm{~min}$ and the rates per plate were averaged. The mean rate of the 2 plates was used as the primary productivity estimate. To detect temporal changes over $17 \mathrm{~d}$, algal biomass in the control treatment was compared to the initial biomass using a 2-tailed $t$-test. We tested our hypothesis that nutrient enrichment would not stimulate primary productivity using paired $t$-tests between the control and each treatment

Algal tissue was removed for carbon and nitrogen content from randomly selected $1 \mathrm{~cm}^{2}$ areas on 5 plates grazed by Diadema antillarum and 5 plates not grazed by sea urchins. Carbonates were removed from the samples with $1 \% \mathrm{HCl}$ followed by a rinse with deionized water. Decalcified samples were filtered onto pre-combusted glass fiber filters, and dried at $60^{\circ} \mathrm{C}$ for $24 \mathrm{~h}$. Carbon and nitrogen content was determined in a Perkin-Elmer $240 \mathrm{~B}$ elemental analyzer using acetanilide as a standard. The nitrogen required to support the measured $\mathrm{O}_{2}$ productivity was calculated from the $\mathrm{C}: \mathrm{N}$ content assuming a $10 \mathrm{~h}$ light period and a photosynthetic quotient of 1.0 .

Respiration and ammonium excretion by Diadema 
antillarum. Diadema antillarum were collected from a patch reef and the forereef at 3 to $5 \mathrm{~m}$ depth from $07: 00$ to 09:00 h local time. The sea urchins were placed in seawater in buckets and immediately returned to the laboratory where they were transferred to tables with flowing seawater.

Experiments began after a minimum acclimation period of $2 \mathrm{~h}$. The maximum test diameter (MTD) of Diadema antillarum was measured to the nearest millimeter using long-jawed calipers and 1 sea urchin was placed in each of 2 aquaria (22 l volume). A third aquarium served as control. D. antillarum were not fed during incubations, although they had access to algal turfs during the acclimation period. Lids fitted with an oxygen probe/stirrer combination (Yellow Springs Instruments) and water sampling ports were sealed over the aquaria with unvulcanized rubber. The aquaria were placed in tables with flowing seawater shaded from direct sunlight. Temperature inside the aquaria was maintained at $26 \pm 2^{\circ} \mathrm{C}$. Changes in dissolved $\mathrm{O}_{2}$ were recorded every $30 \mathrm{~min}$ and water for ammonium and nitrate plus nitrite analyses (Parsons et al. 1984) was withdrawn in triplicate every $2 \mathrm{~h}$ for 8 to $10 \mathrm{~h}$ beginning at 08:00 to 10:00 h local time or at 20:00 to $21: 00 \mathrm{~h}$ for dark experiments. Water was replaced simultaneously through a second sampling port.

Respiration rates of 38 sea urchins were estimated from the decline in dissolved $\mathrm{O}_{2}$ concentration over time. During initial experiments, activity patterns of sea urchins were observed for correlation with respiration rates. Activity was ranked on a scale from 1 to 3 , corresponding to sea urchins climbing aquarium walls (1), moving along the bottom of the aquarium (2), and not moving except for spines (3). Biomass-specific respiration rates were calculated based on the equation:

$$
\ln Y=-0.41198+0.057108 X
$$

where $X=$ MTD; $Y=g$ dry weight of soft and hard parts of Diadema antillarum (Carpenter unpubl.).

Ammonium excretion rates of 40 sea urchins were calculated as the slope of a best-fit regression between ammonium concentration and time. If the change in ammonium concentration over time in the control was significant ( $p<0.05 ; 1$-way analysis of variance), the excretion rate was corrected for the control rate.

Ammonium concentrations under Diadema antillarum resting during the day in the open or in crevices open to light were estimated in water samples taken from under $D$. antillarum with a modified syringe. The needle was placed at the end of a polycarbonate tube that extended $40 \mathrm{~cm}$ from the syringe attachment point and was held rigid by a thin metal rod. Each sample under a sea urchin was paired with a control sample taken with a separate syringe above an algal turf, $>20 \mathrm{~cm}$ away from a sea urchin. Samples were fixed immediately with reagents and shielded from light in a cooler before being returned to the laboratory for analyses.

\section{RESULTS}

\section{Effects of nutrient enrichment on primary productivity of algal turfs}

Ammonium and phosphate concentrations were substantially elevated over control levels in the nutrientenrichment treatments (Table 1). There were no significant differences in biomass or rates of primary productivity of algal turfs on the plates at the start of the nutrient-enrichment experiment $(p>0.05 ; 1$-way analysis of variance). The algal biomass of the control plates did not change significantly from the original biomass after $17 \mathrm{~d}(p>0.05)$ and was representative of previously reported values (Carpenter 1986). Algal bio-

Table 1. Results of nutrient enrichment of algal turfs in St Croix. Mean values \pm standard deviation. $n$ : sample size. Significance tests are for paired 1-tailed $t$-tests between each treatment and control at the end of a $17 \mathrm{~d}$ experiment

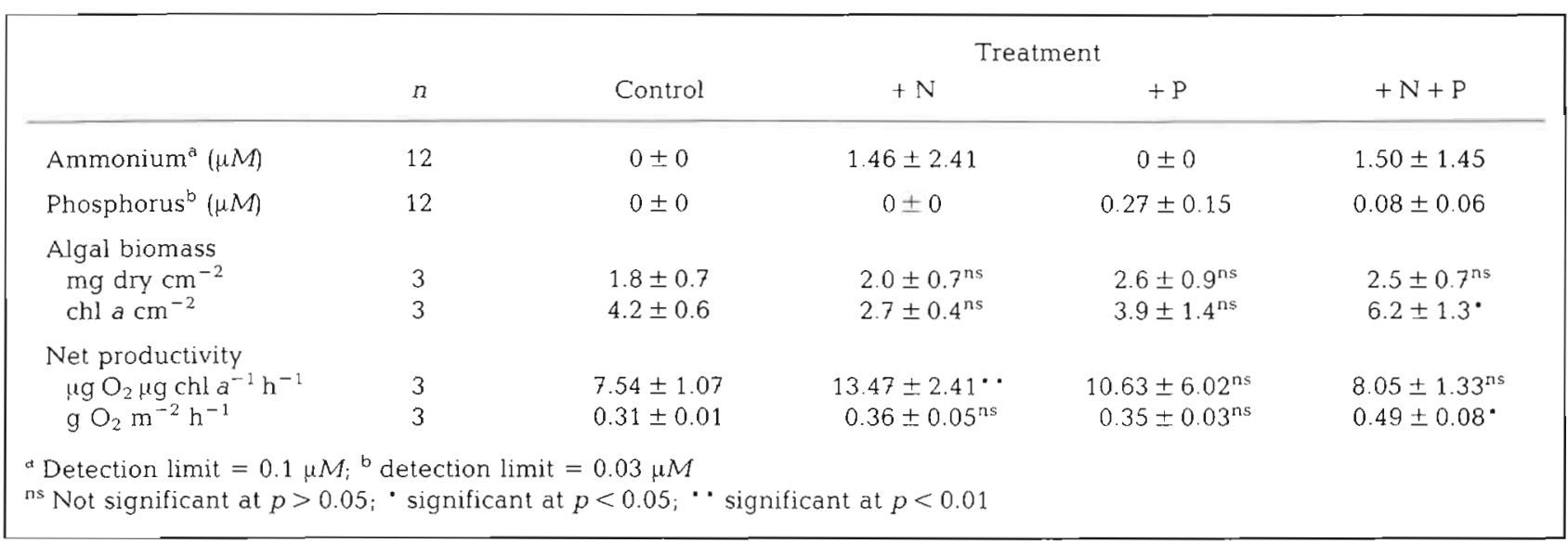


mass in each treatment was not significantly different from the control after $17 \mathrm{~d}(p>0.01$; Table 1$)$, a time substantially greater than the turnover time of $\geq 1 \mathrm{~d}$ for algal turfs (Carpenter 1986). Net primary productivity per unit chl a was significantly greater $(p<0.05)$ in the $+N$ treatment than in the control treatment. Rates of primary productivity in each of the remaining treatments did not differ significantly from the control $(p>0.05)$. Rates of primary productivity per unit area were stimulated significantly only in the $+N+P$ treatment $(p<0.05)$, suggesting a possible synergistic effect of $N$ and $P$. In this treatment, chl $a \mathrm{~cm}^{-2}$ was higher, although algal biomass was similar to other treatments, indicating an increased concentration of chl $a$ in the algal tissue. These results suggest that chlorophyll-specific primary productivity was depressed in the $+\mathrm{N}+\mathrm{P}$ treatment or that a portion of the chl a was inactive in photosynthesis.

\section{Respiration and ammonium excretion by Diadema antillarum}

The decline of $\mathrm{O}_{2}$ in aquaria with sea urchins was always linear, indicating that disturbance of Diadema antillarum had no observable effect on their rates of respiration during the experiments (Fig. 1). Respiration rates ranged from 2.4 to $8.6 \mathrm{mg} \mathrm{O}_{2}$ ind. $^{-1} \mathrm{~h}^{-1}$ and were not significantly different between day $\left(4.47 \mathrm{mg} \mathrm{O}_{2}\right.$ ind. $\left.{ }^{-1} \mathrm{~h}^{-1} \pm 1.48 \mathrm{SD}, n=28\right)$ and night $(3.93 \mathrm{mg} \mathrm{O}$

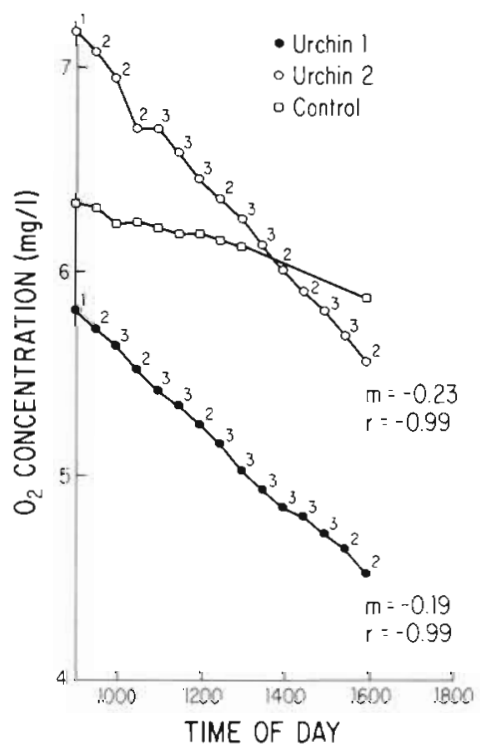

Fig. 1. Example of changes in dissolved $\mathrm{O}_{2}$ over time in aquaria with and without (control) Diadema antillarum. $m$ : slope of least squares regression line; $r$ regression coefficient. Activity of $D$. antillarum is indicated at $0.5 \mathrm{~h}$ intervals: $1=$ climbing walls, $2=$ moving over aquarium floor, $3=$ spine movement only ind. $\left.{ }^{-1} h^{-1} \pm 1.07 \mathrm{SD}, n=10\right)(p>0.05,2$-tailed $t$-test). Respiration rates increased with $D$. antillarum size in the range from 49 to $90 \mathrm{~mm} \mathrm{MTD} \mathrm{(Fig.} \mathrm{2);} \mathrm{however,}$ biomass-specific respiration rates declined with increasing sea urchin biomass (Fig. 3).

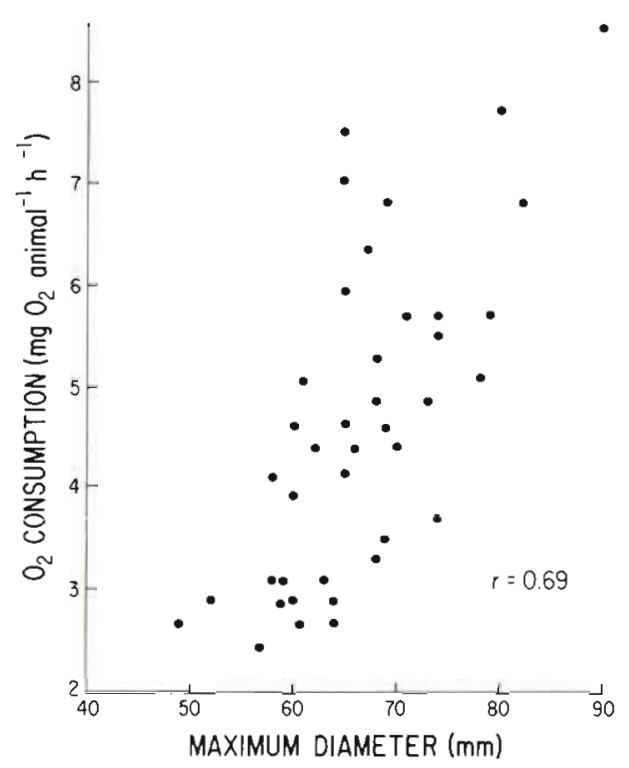

Fig. 2. Diadema antillarum. Respiration as a function of maximum test diameter. $r$ : correlation coefficient

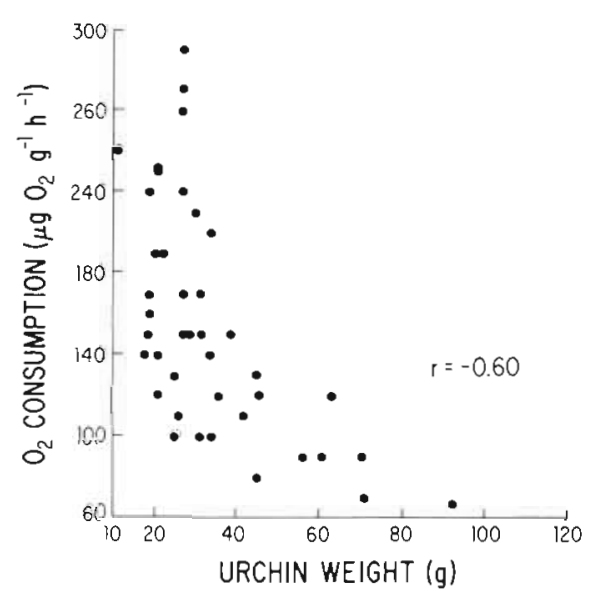

Fig. 3. Diadema antillarum. Respiration rates as a function of sea urchin dry weight. r: correlation coefficient

A typical time course used to calculate ammonium excretion is shown in Fig. 4. Mean ammonium excretion rates were significantly higher during the day $\left(141 \mu \mathrm{g} \mathrm{N}\right.$ ind. $\left.{ }^{-1} \mathrm{~h}^{-1} \pm 84 \mathrm{SD}, n=30\right)$ than at night (38 $\mu \mathrm{g} \mathrm{N}$ ind. $\left.{ }^{-1} \mathrm{~h}^{-1} \pm 18 \mathrm{SD}, n=10\right)(p<0.05 ; 2$-tailed $t$-test). Ca $79 \%$ of the estimated daily excretion occurred during the day when Diadema antillarum is relatively inactive but in proximity to algal turfs. Biomassspecific rates of ammonium excretion were negatively 


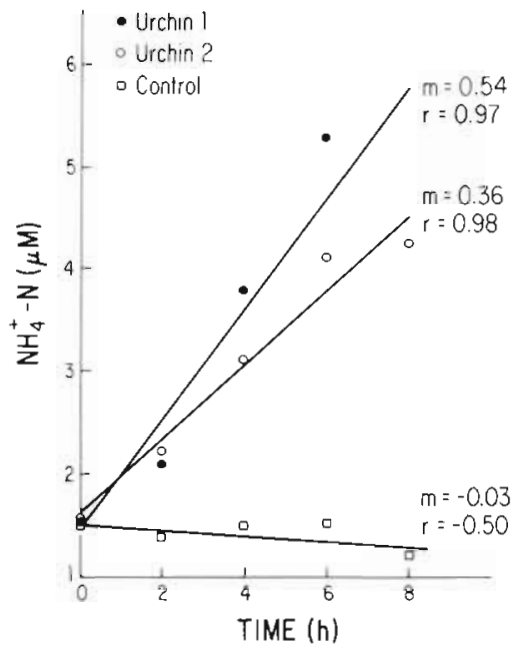

Fig. 4. Example of changes in ammonium concentrations over time in aquaria with and without (control) Diadema antillarum, beginning at $08: 00 \mathrm{~h}$ local time. $\mathrm{m}$ : slope of least squares regression line; $r$ regression coefficient

correlated with sea urchin biomass $(r=0.42$, $p<0.075$ ). Partial correlation analysis, with sea urchin biomass held constant, indicated that biomass-specific excretion rates were positively correlated with biomass-specific respiration rates $(r=0.88, p<0.01)$. Changes in ammonium concentration in the control were relatively small $\left(0.2 \pm 1.1 \mu \mathrm{g} \mathrm{N} l^{-1} \mathrm{~h}^{-1}\right)$. The mean nitrate-plus-nitrite production rate of $0.4 \pm 0.9 \mu \mathrm{g} \mathrm{N} l^{-1}$ $\mathrm{h}^{-1}$ in aquaria with $D$. antillarum was only $1 \%$ of the total combined production of dissolved inorganic nitrogen (Fig. 5). There were no consistent patterns between changes in ammonium and nitrate-plus-nitrite concentrations, suggesting that there were no systematic, and presumably microbially-mediated, transformations of dissolved inorganic nitrogen (e.g. nitrification)

In the field, dissipation of Diadema antillarum excretions was not immediate or complete, suggesting that nitrogenous excretions are likely to be available for uptake by algae. Mean ammonium concentrations of $2.28 \mu M \pm 1.40 \mathrm{SD}$ under $D$. antillarum were significantly higher than adjacent ambient concentrations of $1.04 \mu M \pm 1.03 \mathrm{SD}(p<0.025$, paired 1 -tailed $t$-test $)$. The ambient values reflected contamination of syringes and glassware during the $1 \mathrm{~h}$ period of sampling from a small open boat. Ammonium was undetectable when sampled with a clean bottle and was also undetectable in the initial control sample, but each successive pair of ambient and sea urchin samples contained more ammonium. Because paired comparisons were made, the relative differences between ambient concentrations and those under sea urchins were unaffected. The increase of $1.24 \mu M$ attributable to the presence of

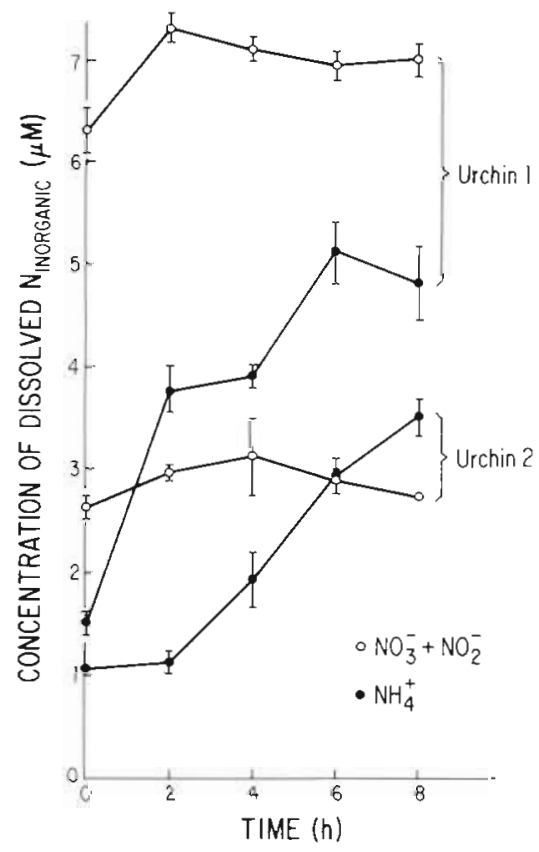

Fig. 5. Changes in nitrate + nitrite and ammonium concentrations over time during an independent Diadema antillarum excretion experiment in 2 chambers beginning at $09: 00 \mathrm{~h}$ local time. Error bars $= \pm 1$ standard deviation

D. antillarum was similar to the average ammonium concentration in the nutrient enrichment experiment (Table 1).

\section{Potential contribution of Diadema antillarum excretion to primary productivity of algal turis}

Based on the above evidence that in nature Diadema antillarum represent microenvironments of elevated ammonium concentrations and that algal turf primary productivity is nitrogen-limited, we calculated the potential contribution of ammonium excretion by $D$. antillarum to the gross primary productivity of algal turfs. We used pre- and post-mortality population densities of $D$. antillarum (Carpenter 1985b) and the mean day $(=10 \mathrm{~h}$ ) plus night excretion rates. We did not use size-specific excretion rates because $D$. antillarum size-class frequencies were not available. The mean $C: N$ content of sea urchin-grazed algal tissue $\{15.0: 1 \pm 1.8: 1 \mathrm{SD})$ for the pre-mortality conditions and that of algal tissue not grazed by sea urchins (11.4:1 \pm 1.6:1 SD) for post-mortality, were used to calculate algal turf nitrogen requirements. Ammonium excretion from $D$. antillarum could supply 6 to $19 \%$ of the estimated nitrogen required for pre-mortality algal turf primary productivity but $<1 \%$ of post-mortality primary productivity (Table 2). 
Table 2. Percentages of the nitrogen requirement of algal turfs that are supplied by Diadema antillarum excretions, based on preand post-mortality population densities, gross primary productivity, and $\mathrm{C}: \mathrm{N}$ ratios of algal turfs

\begin{tabular}{|c|c|c|c|c|c|c|}
\hline Site & $\begin{array}{l}\text { Water } \\
\text { depth } \\
(\mathrm{m})\end{array}$ & $\begin{array}{c}\text { Diadema } \\
\text { density } \\
\left(\text { no. } \mathrm{m}^{-2}\right)\end{array}$ & $\begin{array}{c}\text { Primary } \\
\text { productivity } \\
\left(\mathrm{gC} \mathrm{\textrm {C } ^ { - 2 }} \mathrm{d}^{-1}\right)\end{array}$ & $\begin{array}{c}\text { Nitrogen } \\
\text { requirement } \\
\left(\mathrm{mg} \mathrm{N} \mathrm{m}^{-2} \mathrm{~d}^{-1}\right)\end{array}$ & 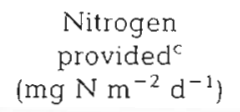 & $\begin{array}{c}\text { N supplied } \\
\text { by excretion } \\
(\%)\end{array}$ \\
\hline \multicolumn{7}{|c|}{ Pre-mortality (December 1983) } \\
\hline Backreef & 2 & 6.4 & 3.18 & 212 & 12 & 6 \\
\hline Forereef & 2 & 13.4 & 2.02 & 135 & 26 & 19 \\
\hline Forereef & 5 & 9.0 & 1.70 & 113 & 17 & 15 \\
\hline Forereef & 10 & 5.8 & 1.13 & 87 & 11 & 13 \\
\hline \multicolumn{7}{|c|}{ Post-mortality (December 1985) } \\
\hline Backreef & 2 & 0.1 & 2.32 & 205 & 0.2 & $<1$ \\
\hline Forereef & 2 & 1.1 & 2.18 & 246 & 2 & $<1$ \\
\hline Forereef & 5 & 0.3 & 2.36 & 207 & 0.6 & $<1$ \\
\hline Forereef & 10 & 0.3 & 1.84 & 161 & 0.6 & $<1$ \\
\hline \multicolumn{7}{|c|}{$\begin{array}{l}\text { a Data from Carpenter }(1985 \mathrm{a}, \mathrm{b}, 1988) \\
{ }^{\mathrm{b}} \mathrm{C}: \mathrm{N} \text { of algal turf }=15: 1 \text { (pre-mortality), } 11.4: 1 \text { (post-mortality) } \\
{ }^{\mathrm{C}} \text { Based on mean day }(=10 \mathrm{~h}) \text { plus night excretory rates }\end{array}$} \\
\hline
\end{tabular}

\section{DISCUSSION}

Few data on sea urchin respiration, and fewer on excretion, are available (for review, see Jangoux \& Lawrence 1982). Our main purpose in measuring respiration was to verify that Diadema antillarum metabolism was stable during measurement of excretion. Respiration rates of $D$. antillarum in our study are within the upper range of values reported for this and other Caribbean regular echinoids (Lewis 1968a, b, Jangoux 1982, Lawrence \& Lane 1982). Ammonium excretion rates are also similar to those previously reported for $D$. antillarum of a similar size class (Lewis 1967, Hawkins \& Lewis 1982). Respiration and excretion rates on a biomass-specific basis are higher for smaller $D$. antillarum, consistent with patterns between size and metabolic activity demonstrated for most organisms (Schmidt-Nielsen 1984).

Higher rates of excretion during the day are not correlated with higher respiration rates but probably are related to the nocturnal feeding activity and diurnal digestion of $D$. antillarum. Food first appears in the hind gut or intestine, where absorption probably occurs (Lewis 1964, Lawrence 1982), 4 h after ingestion (Lewis 1964). Food passes through the gut in 8 to $12 \mathrm{~h}$ (Lewis 1964), suggesting that the majority of digestion occurs during the day in $D$. antillarum. This most likely explains the concomitant higher diurnal rates of excretion. An alternative explanation may be that the sea urchins did not graze the algal turfs provided in the laboratory before the night experiments commenced and had empty guts. D. antillarum rest in proximity to algal turfs during the day and cover only 1 to $2 \mathrm{~m}^{2}$ at night when they sit for periods probably sufficient to provide a buildup of ammonium similar to that measured (Carpenter 1984, pers. obs.). Multicellular marine algae take up ammonium in the dark at a rate that may or may not be lower than in the light, depending on the species and length of the dark period (Haines \& Wheeler 1978, Hanisak \& Harlin 1978, Ryther et al. 1981). Data on kinetics of nutrient uptake by coral reef algal turfs are presently unavailable.

The input of nutrients to plant communities that is mediated by animals is increasingly recognized as an important ecological feature of many plant-animal interactions. Stimulation of primary productivity of grazed plants by herbivore-regulated nutrient inputs has been documented in terrestrial and aquatic ecosystems (Flint \& Goldman 1975, McNaughton 1979, Seale 1980, Newbold et al. 1982, Carpenter \& Kitchell 1984, Sterner 1986). Marine primary producers, such as the giant kelp Macrocystis pyrifera and the coral Acropora palmata, that provide resting areas for fishes benefit from nutrients that the fishes obtain during migrations to adjacent feeding areas (Bray et al. 1981, Meyer et al. 1983). Nitrogenous excretions from fauna associated with temperate seaweeds can provide a critical source of nitrogen for seaweed growth when ambient nitrogen is depleted (Kautsky \& Wallentinus 1980, Probyn \& Chapman 1983). Nitrogenous excretions from Diadema antillarum may provide an example of a herbivoreplant nutrient transfer that fosters high plant productivity in a nutrient-poor environment.

We have demonstrated that primary productivity of algal turfs is limited by nitrogen (Table 1). Potential sources of nitrogen for reef primary productivity are 
advection, $\mathrm{N}_{2}$ fixation, and recycling. To the extent that recycled nitrogen is used, more new nitrogen (sensu Dugdale 1976) will be available for net algal production. Ammonium excreted by Diadema antillarum is available for algal uptake and may potentially supply up to $19 \%$ of the total nitrogen requirements of algal turfs (Table 2). Although it has not been demonstrated that excreted ammonium is taken up by algal turf species, it is reasonable to assume rapid uptake of ammonium when it becomes available in a nitrogenlimited environment (Rosenberg \& Probyn 1984, Thomas \& Harrison 1987). This nitrogen supplement may explain partly why algal turfs grazed by $D$. antillarum are more productive per unit chl a than algal turfs not grazed by $D$. antillarum. Grazing by herbivorous fishes, the other dominant functional group of herbivores on algal turfs (Carpenter 1986. Lewis 1986), does not stimulate the chl $a$-specific productivity of algal turfs. One obvious difference between herbivorous fishes and $D$. antillarum is that $D$, antillarum excretes in much closer proximity to algal turfs. Although recycled nitrogen may not increase the amount of net production available for export from reef ecosystems, it is another mechanism that maintains the high rates of primary productivity of algal turfs on coral reefs. The relative amounts of nitrogen supplied to algal turfs by advection, $\mathrm{N}_{2}$ fixation, and recycling remain to be determined.

Acknowledgements. This work was supported by Sea Grant \# UPR R/ES-40-2 to R. Carpenter and by the West Indies Laboratory. E. Telemaque conducted the respiration/excretion experiments and $\mathrm{H}$. Carpenter and B. Nyden assisted with productivity measurements. Carbon:nitrogen analyses were performed in the laboratory of $\mathrm{Dr} T \mathrm{R}$. Fisher, Jr, University of Maryland.

\section{LITERATURE CITED}

Bak, R. P. M., Carpay, M. J. R., de Ruyter van Steveninck, E D. (1984). Densities of the sea urchin Diadema antillarum before and after mass mortality on the coral reefs of Curaçao. Mar. Ecol. Prog. Ser. 17: 105-108

Ballantine, D. L. (1984). Hurricane-induced mass mortalities to a tropical subtidal algal community and subsequent recoveries. Mar Ecol. Prog. Ser. 20: 75-83

Bray, R. N., Miller, A. C., Geesey, G. G. (1981). The fish connection: a trophic link between planktonic and rocky reef communities. Science 214: 204-205

Carpenter, R. C. (1981). Grazing by Diadema antillarum (Philippi) and its effects on the benthic algal community. $J$. mar. Res. 39: 749-765

Carpenter, R. C. (1984). Predator and population density control of homing behaviour in the Caribbean echinoid Diadema antillarum. Mar. Biol. 82: 101-108

Carpenter, R. C. (1985a). Relationships between primary production and irradiance in coral reef algal communities. Limnol. Oceanogr. 30: 784-793
Carpenter, R. C. (1985b). Sea urchin mass-mortality: effects on reef algal abundance, species composition, and metabolism and other coral reef herbivores. Proc. 5th Int. Coral Reef Symp. 4: 53-59

Carpenter, R. C. (1986). Partitioning herbivory and its effect on coral reef algal communities. Ecol. Monogr. 56: 345-363

Carpenter, R. C. (1988). Mass mortality of a Caribbean sea urchin: immediate effects on community metabolism and other herbivores. Proc natl. Acad. Sci. U.S.A. 85: 511-514

Carpenter, S. R., Kitchell, J. F. (1984). Plankton community structure and limnetic primary production. Am. Nat. 124: 159-172

de Ruyter van Steveninck, E. D., Bak, R. P. M. (1986). Changes in abundance of coral reef bottom components related to mass mortality of the sea urchin Diadema antillarum. Mar. Ecol. Prog. Ser. 34: 87-94

Dugdale, R. C. (1976). Nutrient cycles. In: Cushing, D. H. (ed.) The ecology of the seas. W. B. Saunders, Philadelphia, p. $141-172$

Entsch, B., Sim, R. G., Hatcher, B. G. (1973). Indications from photosynthetic components that iron is a limiting nutrient in primary producers on coral reefs. Mar Biol. 73: 17-30

Flint, R. W., Goldman, C. R. (1975). The effects of a benthic grazer on the primary productivity of the littoral zone of Lake Tahoe. Limnol. Oceanogr. 20: 935-944

Foster, S. A. (1987). The relative impacts of grazing by Caribbean coral reef fishes and Diadema: effects of habitat and surge. J. exp. mar. Biol. Ecol. 105: 1-20

Gladfelter, E. H., Kinsey, D. W. (1985). Metabolism, calcification and carbon production. Proc. 5th. Int. Coral Reef Symp. 4: 503-542

Guerinot, M. L., Patriquin, D. G. (1981). The association of $\mathrm{N}_{2}$ fixing bacteria with sea urchins. Mar. Biol. 62: 197-207

Haines, K. C., Wheeler, P. A. (1978). Ammonium and nitrate uptake by the marine macrophyte Hypnea musciformis (Rhodophyta) and Macrocystis pyrifera (Phaeophyta). J. Phycol. 14. 319-324

Hanisak, M. D., Harlin, M. M. (1978). Uptake of inorganic nitrogen by Codium fragile subsp. tomentosoides (Chlorophyta). J. Phycol. 14: 450-454

Hatcher, B. G. (1981). The interaction between grazing organisms and the epilithic algal community of a coral reef: a quantitative assessment. Proc. 4th Int. Coral Reef Symp. 2 515-524

Hatcher, B. G., Larkum, A. W. D. (1983). An experimental analysis of factors controlling the standing crop of the epilithic algal community on a coral reef. J. exp. mar. Biol. Ecol. 69: 61-84

Hawkins, C. M., Lewis, J. B. (1982). Ecological energetics of the tropical sea urchin Diadema antillarum Philippi in Barbados, West Indies. Estuar. coast. Shelf Sci. 15: 645-669

Jangoux, M. (1982). Excretion. In: Jangoux, M., Lawrence, J. M. (eds.) Echinoderm nutrition. A. A. Balkema, Rotterdam, p. $437-445$

Jangoux, M., Lawrence, J. M. (ed.) (1982). Echinoderm nutrition. A. A. Balkema, Rotterdam

Johannes, R. E., and Project Symbios Team (1971). The metabolism of some coral reef communities: a team study of nutrient and energy flux at Eniwetok. Bioscience 22: 541-543

Kautsky, N., Wallentinus, I. (1980). Nutrient release from a Baltic Mytilus-red algal community and its role in benthic and pelagic productivity. Ophelia 1 (Suppl.): 17-30

Kinsey, D. W., Domm, A. (1974). Effects of fertilization on a coral reef environment-primary production studies. Proc. 2nd. Coral Reef Symp. 1: 49-66 
Koroleff, F. (1976). Determination of $\mathrm{NH}_{4}^{+}-\mathrm{N}$. In: Grasshof, K (ed.) Methods of seawater analysis. Verlag Chemie, Weinheim, p. 127-133

Lawrence, J. M. (1982). Digestion. In: Jangoux, M., Lawrence, J. M. (eds.) Echinoderm nutrition. A. A. Balkema, Rotterdam, p. 283-316

Lawrence, J. M., Lane, J. M. (1982). The utilization of nutrients by postmetamorphic echinoderms. In: Jangoux, M., Lawrence, J. M. (eds.) Echinoderm nutrition. A. A. Balkema Rotterdam, p. 331-371

Lessios, H. A., Robertson, D. R., Cubit, J. D. (1984). Spread of Diadema mass mortality through the Caribbean. Science 226: 335-337

Lewis, J. B. (1964). Feeding and digestion in the tropical sea urchin Diadema antillarum Philippi. Can. J. Zool. 42: $549-557$

Lewis, J. B. (1967). Nitrogenous excretion in the tropical sea urchin Diadema antillarum Philippi. Biol. Bull. mar. biol. Lab, Woods Hole 132: 34-37

Lewis, J. B. (1968a). Respiration in the tropical sea urchin Diadema antillarum Philippi. Physiol. Zool. 41: 476-480

Lewis, J. B. (1968b). Comparative respiration of tropical echinoids. Comp. Biochem. Physiol. 24A: 649-652

Lewis, J. B. (1977). Processes of organic production on coral reefs. Biol Rev. 52: 305-347

Lewis, S. M. (1986). The role of herbivorous fishes in the organization of a Caribbean reef community. Ecol. Monogr. 56: 183-200

Liddell, W. D., Ohlhorst, S. L. (1986). Changes in benthic community composition following the mass mortality of Diadema at Jamaica. J. exp. mar. Biol. Exol. 95: 271-278

Marsh, J. A. (1976). The energetic role of algae in reef ecosystems. Micronesica 12: 13-21

McNaughton, S. J. (1979). Grazing as an optimization process: grass-ungulate relationships in the Serengeti. Am. Nat. 113: 691-703

Meyer, J. L., Schultz, E. T., Helfman, G. S. (1983). Fish schools: an asset to corals. Science 220: 1047-1049

Newbold, J. D., O'Neill, R. V., Elwood, J. W., Van Winkle, W. (1982). Nutrient spiralling in streams: implications for nutrient limitation and invertebrate activity. Am. Nat. 120: $628-652$

Ogden, J. C. (1977). Carbonate-sediment production by parrot fish and sea urchins on Caribbean reefs. In: Frost, S. Weiss, M. (eds.) Caribbean reef systems: Holocene and ancient. Am. Ass. Petrol. Geol. Special Paper 4, p. 281-288

Ogden, J. C., Brown, R. A., Salesky, N. H. (1973). Grazing by the echinoid Diadema antillarum Philippi: formation of halos around West Indian reefs. Science 182: 715-717
Parsons, T. R., Maita, Y, Lalli, C. M. (1984). A manual of chemical and biological methods for seawater analysis. Pergamon Press, New York

Probyn, T A., Chapman, A. R. O. (1983). Summer growth of Chordaria flagelliformis (O. F. Muell.) C. Ag.: physiological strategies in a nutrient stressed environment. J. exp. mar. Biol. Ecol. 73: 243-271

Rosenberg, G., Probyn, T A. (1984). Nutrient uptake and growth kinetics in brown seaweeds: response to continuous and single additions of ammonium. J. exp. mar. Biol. Ecol. 125-146

Ryther, J. H., Corwin, N., DeBusk, T. A., Williams, L. D. (1981). Nitrogen uptake and storage by the red alga Gracilaria tikvahiae (McLachlan, 1979). Aquaculture 26: 107-115

Sammarco. P. W., (1982). Effects of grazing by Diadema antillarum Philippi (Echinodermata: Echinoidea) on algal diversity and community structure. J. exp. mar. Biol. Ecol. 65: 83-105

Sammarco, P. W., Levinton, J. S., Ogden, J. C. (1974). Grazing and control of coral reef community structure by Diadema antillarum Philippi (Echinodermata: Echinoidea): a preliminary study. J. mar. Res. 32: 47-53

Schmidt-Nielsen, K. (1984). Scaling: why is animal size so important? Cambridge University Press, London

Seale, D. B. (1980). Influence of amphibian larvae on primary production, nutrient flux, and competition in a pond ecosystem. Ecology 61: 1531-1550

Smith, S. V. (1984). Phosphorus versus nitrogen limitation in the marine environment. Limnol. Oceanogr. 29: 1149-1160

Steneck, R. S., Watling, L. (1982). Feeding capabilities and limitation of herbivorous molluscs: a functional group approach. Mar. Biol. 68: 229-319

Sterner, R. W. (1986). Herbivores' direct and indirect effects on algal populations. Science 231: 605-606

Thomas, T. E., Harrison, P. J. (1987). Rapid ammonium uptake and nitrogen interactions in five intertidal seaweeds grown under field conditions. J. exp. mar. Biol. Ecol. 107: 1-8

Wanders, J. B. W. (1976). The role of benthic algae in the shallow reef of Curaçao (Netherlands Antilles). I: Primary productivity in the coral reef. Aquat. Bot. 2: 235-270

Wanders, J. B. W. (1977). The role of benthic algae in the shallow reef of Curaçao (Netherlands Antilles). III. The significance of grazing. Aquat. Bot. 3: 357-390

Wilkinson, C. R., Sammarco, P. W. (1983). Effects of fish grazing and damselfish territoriality. II. Nitrogen fixation. Mar. Ecol. Prog. Ser 13: 15-19

Wilkinson, C. R., Williams, D. McB., Sammarco, P. W., Hogg, R. W., Trott, L. A. (1984). Rates of nitrogen fixation on coral reefs across the continental shelf of the central Great Barrier Reef. Mar. Biol. 80: 255-262 